\title{
Do not do in COPD: consensus statement on overuse
}

This article was published in the following Dove Press journal:

International Journal of COPD

\section{Felipe Villar-Álvarez,' Raúl Moreno-Zabaleta, ${ }^{2}$ Jose Joaquin Mira-Solves, ${ }^{3}$ Eduardo Calvo-Corbella, ${ }^{4}$ Salvador Díaz-Lobato, ${ }^{5}$ Fernando González-Torralba, ${ }^{6}$ Ascensión Hernando-Sanz, ${ }^{7}$ Sara Núñez-Palomo, ${ }^{8}$ Sergio Salgado-Aranda, ${ }^{9}$ Beatriz Simón-Rodríguez, ${ }^{10} \mathrm{Paz}$ Vaquero-Lozano,"' Isabel María Navarro-Soler ${ }^{12}$ \\ On behalf of "Do not do in COPD” Working Group of the Madrid Society of Pulmonology and Thoracic Surgery (Neumomadrid)}

'Department of Pulmonology, IIS-Fundación Jiménez Díaz, CIBERES, UAM, ${ }^{2}$ Pulmonology, Inpatient and Noninvasive Mechanical Ventilation, Hospital Universitario Infanta Sofía, Madrid, ${ }^{3}$ Alicante-Sant Joan Health District, Alicante/Universidad Miguel Hernández Elche/REDISEC, ${ }^{4}$ Family and Community Medicine, CSU Pozuelo Estación, School of Medicine, UAM, ${ }^{5}$ Department of Pulmonology, Hospital Ramón y Cajal, Madrid, 'Pulmonology Section, Hospital Universitario del Tajo, Aranjuez, ${ }^{7}$ Department of Pulmonology, Hospital Universitario 12 de Octubre, ${ }^{8}$ C.S. Torrelaguna, ${ }^{9}$ Pulmonology Section, Hospital del Sureste, ${ }^{10}$ FisioRespiraciónRespiratory Physiotherapy Unit, Escuela Universitaria Gimbernat Cantabria, "S. Pulmonology, CEP Hnos. Sangro HGU Gregorio Marañón, Madrid, ${ }^{12}$ Calitè Research Group, Universidad Miguel Hernández de Elche, Elche, Spain

Correspondence: Felipe Villar-Álvarez Department of Pulmonology, IIS-Fundación Jiménez Díaz, CIBERES, UAM, Av Reyes Católicos 2, Madrid 28049, Spain

Email fvillarleon@yahoo.es
Background: To identify practices that do not add value, cause harm, or subject patients with chronic obstructive pulmonary disease (COPD) to a level of risk that outweighs possible benefits (overuse).

Methods: A qualitative approach was applied. First, a multidisciplinary group of healthcare professionals used the Metaplan technique to draft and rank a list of overused procedures as well as self-care practices in patients with stable and exacerbated COPD. Second, in successive consensus-building rounds, description files were created for each "do not do" (DND) recommendation, consisting of a definition, description, quality of supporting evidence for the recommendation, and the indicator used to measure the degree of overuse. The consensus group comprised 6 pulmonologists, 2 general practitioners, 1 nurse, and 1 physiotherapist.

Results: In total, 16 DND recommendations were made for patients with COPD: 6 for stable COPD, 6 for exacerbated COPD, and 4 concerning self-care.

Conclusion: Overuse poses a risk for patients and jeopardizes care quality. These 16 DND recommendations for COPD will lower care risks and improve disease management, facilitate communication between physicians and patients, and bolster patient ability to provide self-care.

Keywords: COPD, consensus, patient safety, quality assurance

\section{Introduction}

Overuse of resources for diagnosis and therapy puts patients at risk without providing sufficient clinical benefit. Moreover, overuse has cost implications and has been linked to errors in clinical treatment. ${ }^{1,2}$ We must seek to eliminate practices that run contrary to existing evidence; these include carrying out procedures that do not add value for the patient and/or subject patients to unnecessary risk and failing to take actions that have been shown to produce favorable patient outcomes.

Reports in the literature have described this phenomenon using the terms "overuse," "overdiagnosis," "overmedicalization," and "low-value care." 2,3 According to the definition of the Institute of Medicine, overuse consists of providing healthcare when there is no evidence in support of such decisions or when the benefit of the treatment fails to outweigh its risk. ${ }^{1,2}$

Overuse has been linked to unsafe, inappropriate, and/or inefficient care. ${ }^{1,2}$ To counter this trend, the movement called "Less is more medicine" has taken hold in recent years. ${ }^{3}$ Driven by scientific societies, medical associations and institutions, and healthcare authorities across different countries, in recent years there has been a growing effort to eliminate certain aspects of medical practice that have been broadly shown to be inappropriate. ${ }^{4-6}$ Examples of this include initiatives by scientific institutions and 
societies to issue "do not do" (DND) guidelines and informational and educational campaigns urging practitioners to "choose wisely."

In an attempt to encourage patient participation in these measures, the foundation Advancing Medical Professionalism to Improve Health Care (ABIM) ${ }^{6}$ conducted an awarenessraising campaign among patients and care professionals to prevent improper use of resources within diagnosis and therapy. There is a well-known body of improper healthrelated beliefs and behaviors among patients, and these habits lead to harmful practices that must be eradicated if health outcomes are to be improved..$^{4-6}$

Chronic obstructive pulmonary disease (COPD) varies in prevalence from country to country ${ }^{7}$ in Spain, the prevalence of COPD is $10.2 \%$ among adults between the ages of 40 and $80 .{ }^{8}$ Of all the most prevalent illnesses, COPD is the only one that is on the rise. ${ }^{9}$ COPD is currently the third leading cause of death, behind ischemic heart disease and stroke. ${ }^{9}$ One of the main problems with this disease is underdiagnosis. ${ }^{10}$ The burden the disease poses for healthcare resources is substantial: the European Union estimates that the direct cost of COPD totals 38.6 billion euros in Europe, whereas the disease burden in the United States is also high, at 29.5 billion dollars. ${ }^{11,12}$

Major clinical guidelines for management of COPD, such as the Global Initiative for Chronic Obstructive Lung Disease (GOLD), an international standard, ${ }^{13}$ or the Spanish COPD guidelines (GesEPOC), ${ }^{14}$ establish a series of recommendations on preventing, diagnosing, and treating this disease, both for stable as well as exacerbated cases, including indications adapted for different care levels.

Clinical guidelines advise healthcare professionals on appropriate procedures for diagnosis, treatment, and follow-up in step with evolving knowledge of the disease. ${ }^{13,14}$ Despite this information, guides are not always applied correctly and a number of inappropriate practices persist with a certain degree of frequency. ${ }^{15-17}$ Overuse continues in practice (defensive medicine or pressure from patients or relatives are common causes). ${ }^{18,19}$ Moreover, the patient's health beliefs, customs, or misinterpretation could be causes of harm during self-care. These suboptimal measures can be ineffective, inefficient, or even deleterious for patients. ${ }^{19}$ Making changes to routine clinical practice is less than simple, and requires sustained effort in the benefit of effective care. For this reason, a DND approach like the one presented here is useful in that it calls attention to certain aspects of clinical practice that were once widespread but are now known to be inappropriate - because there is no proof of their efficacy, due to scant or doubtful effectiveness, or because they are not cost-effective. ${ }^{1}$

This study aims to identify practices in diagnosis, therapy, and self-care of stable and exacerbated COPD that are inappropriate, have doubtful effectiveness, or are scarcely costeffective, and develop a list of DND recommendations for COPD health professionals and patients.

\section{Materials and methods}

A qualitative research approach was applied. Qualitative research methods analyze phenomena from an overall perspective, attempting to describe reality without formulating hypotheses or setting concrete measures, thereby distinguishing them from quantitative approaches. ${ }^{20}$

This study was carried out in two phases. The first phase comprised an exploratory analysis (using the Metaplan technique), in which we created a list of overused practices, whereas in the second phase we aimed to reach a consensus definition of DND guidelines pertaining to practices that are still relatively common despite the fact that evidence makes a clear case that they have a poor risk-benefit ratio (using a consensus conference technique).

The Spanish health system is mainly a public system in which COPD patients are evaluated, at first, by general practitioners, who initiate the treatment and send the patient to a pulmonologist to complete the evaluation. If there is a problem in the evaluation of the patient, the general practitioner begins the treatment. Some COPD patients are treated by physiotherapists and most of them are evaluated by nurses. Therefore, a panel with several pulmonologists, general practitioners, physiotherapists, and nurses is adequate to make a correct evaluation. Ten healthcare professionals participated in this study, each with $>10$ years' experience in treating COPD patients and involved in research and committees in their professional groups and healthcare levels. This group of collaborators was chosen to include a variety of perspectives drawn from different experiences with clinical practice and by balancing primary and in-hospital care. To do this, six pulmonologists (with experience in hospitalization, consultation, emergencies, home care, mechanical ventilation, and healthcare administration), two general practitioners, one nurse, and one physiotherapist were recruited by the Board of Neumomadrid (Madrid Society of Pulmonology and Thoracic Surgery). Two of the expert pulmonologists and a researcher with expertise in qualitative approaches acted as coordinators.

Once the working group had been formed, both the pulmonologist coordinators and the expert in qualitative research 
designed an action plan that called for an initial meeting to be attended by all specialists involved, so as to brainstorm care or self-care practices used in COPD having benefits that do not outweigh their risks. Poor risk-benefit ratio was understood as doubtful effectiveness or deleterious patient outcomes, thus indicating that they were not cost-effective. During this first meeting, the group debated the frequency with which these practices are employed and the strength of the evidence used to deter continued use of these practices. The Metaplan technique ${ }^{21,22}$ was used to identify such practices, to elaborate on them, and to rank them based on frequency. All members of the group began the analysis by noting down the practices they considered to be ill-advised. Based on the results of this method, a decision was made to ask three questions to be answered consecutively (Figure 1):

1) Indicate which practices you consider to be both widely used in the management of patients with stable COPD and also inappropriate because of their poor risk-benefit ratio.

2) Indicate which practices you consider to be both widely used in the management of patients with exacerbated COPD and also inappropriate because of their poor risk-benefit ratio.
3) Indicate which self-care practices you believe are widespread among COPD patients and are inappropriate because of their poor risk-benefit ratio.

Responses to these questions were gathered individually, and each collaborator was able to present as many practices as they saw fit. Similar questions were grouped together. Subsequently, an open, unmoderated debate was held to discuss each of the examples of overuse that had been proposed in the previous phase so that the participants could assess the pertinence, degree of consensus, and sources of evidence for each one. Lastly, each individual coauthor evaluated the different proposed inappropriate practices according to the degree of prevalence in routine clinical practice. For this, a scale of 1-5 was employed, with 1 indicating scarce frequency of use and 5 representing practices that are relatively frequent despite being inadvisable or not cost-effective - that is, those practices discouraged by scientific evidence or professional consensus. In addition, the analysis took into account proposals referring to the same practice which were made by more than one study participant (spontaneity) and the level of agreement between participants (coefficient of variation). During this initial phase, scores around the 75th percentile were considered the cutoff; therefore, practices

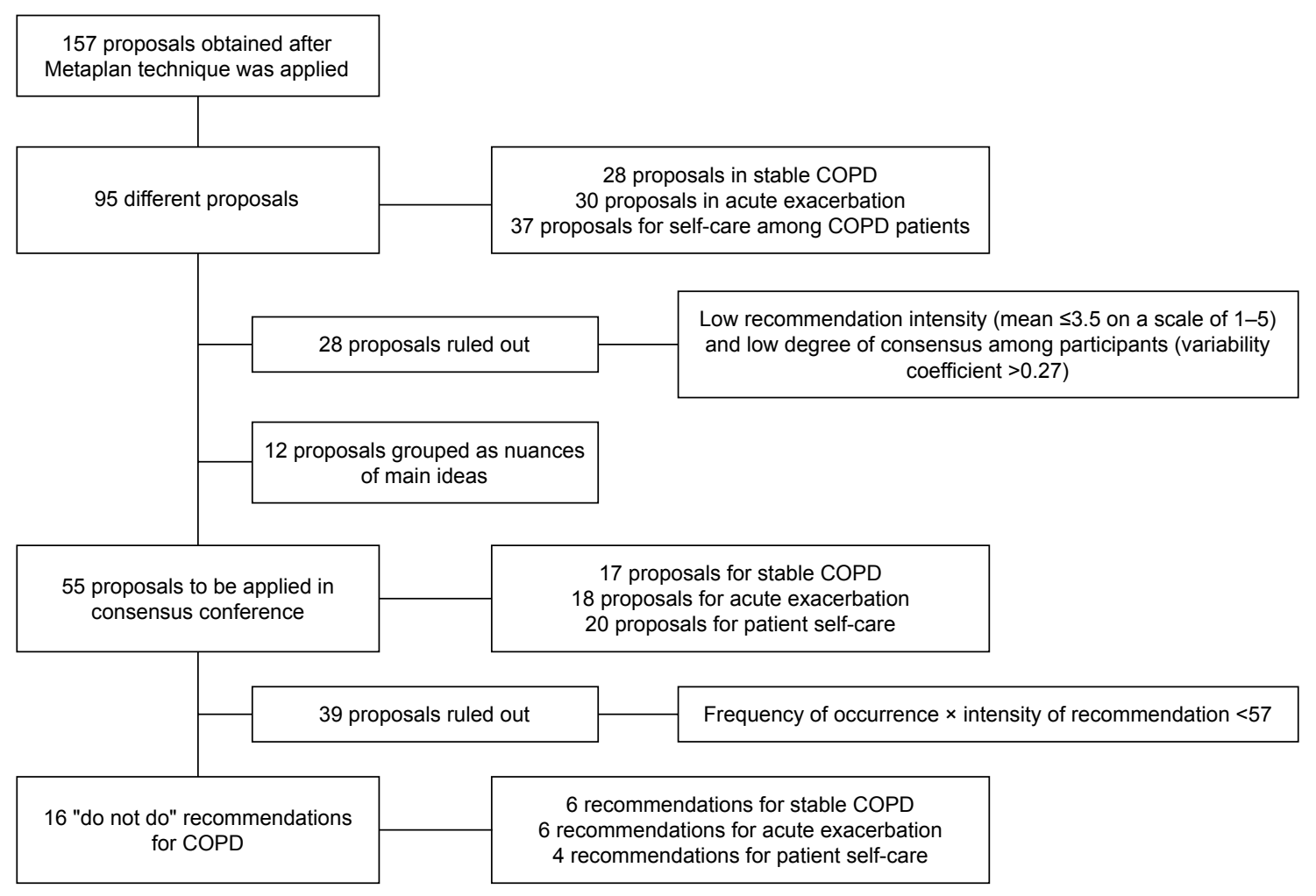

Figure I Summary of the methodology used in the study, including the number of ideas identified, selection criteria, and procedure used to screen "do not do" recommendations in COPD.

Abbreviation: COPD, chronic obstructive pulmonary disease. 
that had been given an average score of 3.5 points or lower, as it was believed that there was no consensus opinion indicating that these were in widespread use (variability coefficient $>0.27$; Figure 1), were proposed as inappropriate.

The methodology used in the second phase was the consensus conference. ${ }^{23}$ For this, a web application was used to select DND recommendations that were most widely chosen. Each inappropriate practice was assigned a DND recommendation.

To assign each DND recommendation, all inappropriate practices were individually assessed (a scale from 1 to 10 was used) again by the group of experts to establish their perceived frequency of use, the degree to which the practice was considered useless, deleterious, or failed to add value, and, lastly, whether the practice was more prevalent among specialists in pulmonology, primary care, or nursing. Moreover, this phase included an opportunity for the collaborators to propose modifications and clarifications to the language used in the originally proposed description of these inappropriate practices. The expert participants had been given information on the degree of consensus reached in the previous phase for each practice perceived to be inappropriate (ie, mean, spontaneity, and coefficient of variation). These recommendations were ranked according to the result obtained by applying the formula frequency $\times$ intensity (range 1-100) once they were grouped according to COPD into stable, exacerbated, or related to self-care. We set a data-driven cutoff point of 57 points, meaning that scores below this value indicated a lower level of consensus (Figure 1).

An operational description was created for each of the recommendations processed according to this method, and we evaluated the level of evidence justifying the proposed inappropriateness of the measure. For proposals made for patient self-care, we based these assessments on literature concerning patient education and clinical experience. The resulting recommendations were distributed among the participants, and a descriptive file was created for each one, including the following fields: recommendation title, operative definition of the practice to be eradicated, description of the practice to be eradicated, justification given for the eradication proposal, level of evidence and recommendation grade according to the Scottish Intercollegiate Guidelines Network (SIGN), ${ }^{24}$ bibliographical sources, and recommended indices to assess whether a change has taken place in the practice and to enable follow-up of the level of uptake of these DND recommendations (Figure 2).

\begin{tabular}{|l|}
\hline Practices discouraged for treatment of COPD \\
\hline Name: \\
\hline Operative definition of the practice that should be \\
discontinued: \\
\hline Description: \\
\hline Justification/remarks: \\
\hline Evidence: \\
Strength of recommendation: \\
References:
\end{tabular}

Figure 2 Description file for each "do not do" recommendation in COPD. Abbreviation: COPD, chronic obstructive pulmonary disease.

\section{Results}

When the Metaplan technique was applied, a total of 157 proposals were made concerning overuse practices in the treatment of patients with COPD, and 95 of these were intrinsically different from each other. Practices were eliminated if they received an average score of 3.5 points or lower, as it was believed that there was no consensus opinion surrounding them. This resulted in a total of 28 practices in stable COPD, 30 in exacerbated disease, and 37 self-care practices. Finally, we eliminated 40 examples of inappropriate practices for which there was insufficient consensus among the members of the research group or because they overlapped with others.

During the final phase, which consisted of a consensus conference, 55 proposals were assessed for possible inappropriateness or cost-ineffectiveness, and each one was assigned a DND recommendation: 17 for stable COPD, 18 for exacerbated COPD, and 20 concerning self-care among this population of patients. After the list was reviewed by the group of experts taking part in the study, the number of recommendations was reduced to 16 (after applying the formula frequency $\times$ intensity, and eliminating those recommendations with $<57$ points): six for stable disease, six for exacerbated COPD, and four for patient selfcare (Table 1). 
Table I Practices in diagnosis, therapy, and self-care determined to be ill-advised for COPD patients following a consensus conference

\begin{tabular}{|c|c|c|c|c|c|c|}
\hline \multirow[t]{2}{*}{ Group } & \multirow[t]{2}{*}{ “Do not do" recommendations } & \multicolumn{2}{|l|}{$\mathbf{F}$} & \multicolumn{2}{|l|}{ I } & \multirow{2}{*}{$\frac{\mathbf{F} \times \mathbf{I}}{\text { Mean }}$} \\
\hline & & Mean & $\begin{array}{l}\text { Level of } \\
\text { agreement }\end{array}$ & Mean & $\begin{array}{l}\text { Level of } \\
\text { agreement }\end{array}$ & \\
\hline \multirow[t]{6}{*}{$\begin{array}{l}\text { Patients } \\
\text { with stable } \\
\text { COPD }\end{array}$} & $\begin{array}{l}\text { Do not administer inhaled corticosteroids as routine treatment for } \\
\text { patients with } \mathrm{FEV},>60 \% \text { and }<2 \text { acute exacerbations in the previous } \\
\text { year or in patients without an overlapping COPD-asthma phenotype. }\end{array}$ & 8.6 & 0.10 & 8.3 & 0.10 & 72.2 \\
\hline & $\begin{array}{l}\text { Do not neglect to perform spirometry as part of the diagnostic work-up } \\
\text { in patients with a past history of smoking and symptoms of COPD. }\end{array}$ & 8.3 & 0.21 & 8.3 & 0.11 & 68.9 \\
\hline & $\begin{array}{l}\text { Do not assume that patients correctly administer inhaled medication in } \\
\text { the absence of proper confirmation. }\end{array}$ & 8.0 & 0.13 & 8.5 & 0.15 & 68.0 \\
\hline & $\begin{array}{l}\text { Do not initiate treatment without previously confirming the diagnosis by } \\
\text { spirometry. }\end{array}$ & 8.0 & 0.24 & 8.4 & 0.17 & 67.2 \\
\hline & $\begin{array}{l}\text { Do not change inhaled treatment without first assessing treatment } \\
\text { compliance. }\end{array}$ & 7.9 & 0.26 & 7.7 & 0.12 & 60.8 \\
\hline & $\begin{array}{l}\text { Do not perform pulmonary function testing systematically at each } \\
\text { follow-up visit if there is no change in symptoms, in the number of } \\
\text { previous acute exacerbations, or in treatment. }\end{array}$ & 7.6 & 0.27 & 7.7 & 0.25 & 58.5 \\
\hline Patients with & Do not prescribe antibiotic treatment in all cases of acute exacerbation. & 8.8 & 0.19 & 8.2 & 0.15 & 72.2 \\
\hline exacerbated & Do not prescribe nebulized medication in all cases of acute exacerbation. & 8.1 & 0.21 & 7.8 & 0.19 & 63.2 \\
\hline \multirow[t]{4}{*}{ COPD } & $\begin{array}{l}\text { Do not administer high-flow oxygen if oxygen saturation is }>90 \% \text { or if } \\
\mathrm{PaO}_{2} \text { is } \geq 60 \mathrm{mmHg} \text {. }\end{array}$ & 7.0 & 0.20 & 9.0 & 0.12 & 63.0 \\
\hline & $\begin{array}{l}\text { Do not prescribe home oxygen therapy following an acute exacerbation } \\
\text { if } \mathrm{PaO}_{2} \text { is } \geq 60 \mathrm{mmHg} \text {. }\end{array}$ & 7.5 & 0.31 & 8.2 & 0.19 & 61.5 \\
\hline & $\begin{array}{l}\text { Do not prescribe corticosteroid therapy for periods of }>14 \text { days or } \\
\text { with progressive reduction in therapy. }\end{array}$ & 8.2 & 0.16 & 7.4 & 0.22 & 61.2 \\
\hline & Do not perform spirometry in patients with known COPD. & 6.9 & 0.38 & 8.4 & 0.13 & 58.0 \\
\hline $\begin{array}{l}\text { Self-care in } \\
\text { patients with }\end{array}$ & $\begin{array}{l}\text { Do not discontinue taking inhaled medication because an improvement } \\
\text { in clinical symptoms has taken place. }\end{array}$ & 7.7 & 0.21 & 9.0 & 0.07 & 69.3 \\
\hline \multirow[t]{3}{*}{ COPD } & Do not use the inhaler incorrectly. & 7.2 & 0.18 & 9.0 & 0.12 & 64.8 \\
\hline & Do not stop walking due to feelings of dyspnea. & 7.9 & 0.15 & 7.8 & 0.22 & 61.6 \\
\hline & Do not take unprescribed treatments. & 7.1 & 0.10 & 8.5 & 0.16 & 60.3 \\
\hline
\end{tabular}

Notes: F, frequency of occurrence of the discouraged practice; I, degree of inappropriateness of the discouraged practice; $F \times I$, frequency of occurrence of the practice multiplied by its degree of inappropriateness. Mean, average value from 0 to 10 . This is estimated using the coefficient of variation obtained when each recommendation is evaluated. Lower coefficients of variation indicate greater degrees of homogeneity of assessments and thus greater degrees of consensus.

Abbreviations: COPD, chronic obstructive pulmonary disease; $\mathrm{FEV}_{1}$, forced expiratory volume in I second; $\mathrm{PaO}_{2}$, partial pressure of oxygen.

The definitive list of six DND recommendations for stable COPD was as follows:

- Do not administer inhaled corticosteroids as routine treatment in patients with forced expiratory volume in 1 second $\left(\mathrm{FEV}_{1}\right)>60 \%$ and $<2$ acute exacerbations in the previous year or in patients without an overlapping COPD-asthma phenotype.

- Do not neglect to perform spirometry as part of the diagnostic work-up in patients with a past history of smoking and symptoms of COPD.

- Do not assume that patients correctly administer inhaled medication in the absence of proper confirmation.

- Do not initiate treatment without previously confirming the diagnosis by spirometry.

- Do not change inhaled treatment without first assessing treatment compliance.
- Do not perform pulmonary function testing systematically at each follow-up visit if there is no change in symptoms, in the number of previous acute exacerbations, or in treatment. Six other DND recommendations, which concerned acute exacerbations of COPD, were as follows:

- Do not prescribe antibiotic treatment in all cases of acute exacerbation.

- Do not prescribe nebulized medication in all cases of acute exacerbation.

- Do not administer high-flow oxygen if oxygen saturation is $>90 \%$ or if partial pressure of oxygen $\left(\mathrm{PaO}_{2}\right)$ is $\geq 60 \mathrm{mmHg}$.

- Do not prescribe home oxygen therapy following an acute exacerbation if $\mathrm{PaO}_{2}$ is $\geq 60 \mathrm{mmHg}$.

- Do not prescribe corticosteroid therapy for periods of $>14$ days or with progressive reduction in therapy. 
- Do not perform spirometry in patients with known COPD.

Lastly, the four DND recommendations for self-care among patients with COPD were as follows:

- Do not discontinue taking inhaled medication because an improvement in clinical symptoms has taken place.

- Do not use the inhaler incorrectly.

- Do not stop walking due to feelings of dyspnea.

- Do not take unprescribed treatments.

Subsequently, descriptive files containing technical specifications of each recommendation were created (Figure 2). This file included the level of evidence and grade of recommendation - bases that justify DND recommendations - as well as indicators that allow for an assessment of the data collected (Tables 2 and 3). Clinical guidelines, such as $\mathrm{GOLD}^{13}$ or GesEPOC, ${ }^{14}$ have been evaluated in the level of evidence and in the analysis of data collected.

\section{Discussion}

Using a multi-phase methodology we identified a number of practices used in diagnosis, therapy, and other care including the self-care procedures that are the responsibility of patients - that are inappropriate, have doubtful effectiveness, or are not cost-effective for COPD patients. The results of this study should bring about an increase in care quality by reducing the frequency of practices that add no value or are harmful for patients, as well as by increasing patient safety, improving physician-patient communication, and better enabling patients to undertake self-care.

The National Physicians Alliance, a medical organization operating in the United States, set in motion a project called "Choosing Wisely," which called on a variety of medical societies - initially, those concerned with primary care, internal medicine, and pediatrics - to propose a list of five recommendations for medical practices with the aim of optimizing healthcare resources used to diagnose and treat different illnesses. ${ }^{6}$ In the United Kingdom, the National Institute for Health and Care Excellence (NICE) has also published a set of DND recommendations, highlighting care practices that do not benefit patients or for which there is insufficient evidence upon which to base suggestions for use. ${ }^{25}$

Along these same lines, the American Thoracic Society (ATS), in partnership with the American College of Chest Physicians, created a list of five practices that are widely used to treat respiratory diseases in adults but that, nonetheless, should be avoided. ${ }^{26}$ Although none of these concern COPD, the previous list of ten practices contained two that are relevant to COPD - that is, "Do not perform frequent spirometry in patients with COPD in patients who are clinically stable and
Table 2 Level of evidence and grade of recommendation as indicated in SIGN ${ }^{24}$ including bases that justify the "do not do" recommendations

\begin{tabular}{|c|c|c|}
\hline Group & $\begin{array}{l}\text { Name of the practice } \\
\text { with level of evidence and } \\
\text { grade of recommendation }\end{array}$ & $\begin{array}{l}\text { Bases that justify the } \\
\text { recommendation } \\
\text { (References) }\end{array}$ \\
\hline \multirow[t]{6}{*}{$\begin{array}{l}\text { Patients } \\
\text { with stable } \\
\text { COPD }\end{array}$} & $\begin{array}{l}\text { Do not administer inhaled } \\
\text { corticosteroids as routine } \\
\text { treatment in patients with } \\
\mathrm{FEV},>60 \% \text { and }<2 \text { acute } \\
\text { exacerbations in the previous } \\
\text { year or in patients without an } \\
\text { overlapping COPD-asthma } \\
\text { phenotype. } \\
\text { Level of evidence: I++ } \\
\text { Grade of Recommendation: A }\end{array}$ & $\begin{array}{l}\text { GOLD } \\
\text { Miravitlles et a }\left.\right|^{32} \\
\text { Vogelmeier et } \mathrm{a}^{33} \\
\text { Zhong et al }{ }^{34} \\
\text { Price et a }\left.\right|^{35} \\
\text { Vestbo et a }{ }^{36} \\
\text { Suissa et a }\left.\right|^{37} \\
\text { Wedzicha et } \mathrm{al}^{38}\end{array}$ \\
\hline & $\begin{array}{l}\text { Do not neglect to perform } \\
\text { spirometry as part of the } \\
\text { diagnostic work-up in patients } \\
\text { with a past history of smoking } \\
\text { and symptoms of COPD. } \\
\text { Level of evidence: } 2++ \\
\text { Grade of Recommendation: B }\end{array}$ & $\begin{array}{l}\text { Zwar et } \mathrm{al}^{39} \\
\text { Dirven et } \mathrm{al}^{40} \\
\text { GOLD }^{13} \\
\text { EPOC }^{41}\end{array}$ \\
\hline & $\begin{array}{l}\text { Do not assume that patients } \\
\text { correctly administer inhaled } \\
\text { medication in the absence of } \\
\text { proper confirmation. } \\
\text { Level of evidence: } 2+ \\
\text { Grade of Recommendation: C }\end{array}$ & $\begin{array}{l}\text { Sriram and Percival }{ }^{42} \\
\text { Ingebrigtsen et } \mathrm{a}^{43} \\
\text { Plaza et a }{ }^{44} \\
\text { Vestbo et } \mathrm{al}^{45} \\
\text { Alexopoulos et } \mathrm{al}^{46} \\
\text { Wei et al }{ }^{47} \\
\text { Tommelein et al }{ }^{48} \\
\text { Leiva-Fernández et al }{ }^{49} \\
\text { Bryant et al }{ }^{50}\end{array}$ \\
\hline & $\begin{array}{l}\text { Do not initiate treatment } \\
\text { without previously confirming } \\
\text { the diagnosis by spirometry. } \\
\text { Level of evidence: } 2++ \\
\text { Grade of Recommendation: B }\end{array}$ & $\begin{array}{l}\text { Fernández Villar et al }\left.\right|^{51} \\
\text { Buffels et al }^{52} \\
\text { Hardie et a }{ }^{53} \\
\text { Jones et a }{ }^{54} \\
\text { Miravitlles et al }{ }^{55} \\
\text { Miller and Levy }{ }^{56}\end{array}$ \\
\hline & $\begin{array}{l}\text { Do not change inhaled } \\
\text { treatment without first } \\
\text { assessing treatment compliance. } \\
\text { Level of evidence: } 2+ \\
\text { Grade of Recommendation: C }\end{array}$ & $\begin{array}{l}\text { Sriram and Percival }{ }^{42} \\
\text { Ingebrigtsen et } \mathrm{a}^{43} \\
\text { Melani and Paleari } \\
\text { Braido et } \mathrm{al}^{58} \\
\text { Plaza et } \mathrm{a}^{44}\end{array}$ \\
\hline & $\begin{array}{l}\text { Do not perform pulmonary } \\
\text { function testing systematically } \\
\text { at each follow-up visit if there } \\
\text { is no change in symptoms, } \\
\text { in the number of previous } \\
\text { acute exacerbations, or in } \\
\text { treatment. } \\
\text { Level of evidence: } 4 \\
\text { Grade of Recommendation: D }\end{array}$ & $\begin{array}{l}\text { Kohansal et } \mathrm{a}^{59} \\
\text { Donaldson et al } \\
\text { GOLD }^{13} \\
\text { Miravitlles et } \mathrm{al}^{12} \\
\text { EPOC } \\
\text { Peces-Barba et } \mathrm{al}^{62}\end{array}$ \\
\hline $\begin{array}{l}\text { Patients with } \\
\text { exacerbated } \\
\text { COPD }\end{array}$ & $\begin{array}{l}\text { Do not prescribe antibiotic } \\
\text { treatment in all cases of acute } \\
\text { exacerbation. } \\
\text { Level of evidence: I+ } \\
\text { Grade of Recommendation: A }\end{array}$ & $\begin{array}{l}\text { Sapey and Stockley } \\
\text { Vollenweider et al }\left.\right|^{64} \\
\text { Soler et al }{ }^{65} \\
\text { Miravitlles et a }\left.\right|^{66} \\
\text { Boixeda et } \mathrm{al}^{67}\end{array}$ \\
\hline
\end{tabular}

(Continued) 
Table 2 (Continued)

\begin{tabular}{|c|c|c|}
\hline & $\begin{array}{l}\text { Name of the practice } \\
\text { with level of evidence and } \\
\text { grade of recommendation }\end{array}$ & $\begin{array}{l}\text { Bases that justify the } \\
\text { recommendation } \\
\text { (References) }\end{array}$ \\
\hline & $\begin{array}{l}\text { Do not prescribe nebulized } \\
\text { medication in all cases of } \\
\text { acute exacerbation. } \\
\text { Level of evidence: I++ } \\
\text { Grade of Recommendation: A }\end{array}$ & $\begin{array}{l}\text { Turner et a }\left.\right|^{68} \\
\text { Brocklebank et a }{ }^{69} \\
\text { Dolovich et } \mathrm{al}^{70} \\
\text { Tashkin et a } \mathrm{a}^{71}\end{array}$ \\
\hline & $\begin{array}{l}\text { Do not administer high- } \\
\text { flow oxygen if oxygen } \\
\text { saturation is }>90 \% \text { or if } \mathrm{PaO}_{2} \\
\text { is } \geq 60 \mathrm{mmHg} \text {. } \\
\text { Level of evidence: I++ } \\
\text { Grade of Recommendation: A }\end{array}$ & $\begin{array}{l}\text { Royal United Hospital } \\
\text { Bath }^{72} \\
\text { Driscoll et al }{ }^{73} \\
\text { Rachmale et } \mathrm{al}^{74} \\
\text { Miravitlles et al } \\
\text { American Thoracic } \\
\text { Society } \\
\text { BTS }^{77} \\
\text { Barberá et al }{ }^{78} \\
\text { Siafakas et al }{ }^{79} \\
\text { Pauwels et al }{ }^{80}\end{array}$ \\
\hline & $\begin{array}{l}\text { Do not prescribe home } \\
\text { oxygen therapy following an } \\
\text { acute exacerbation if } \mathrm{PaO}_{2} \\
\text { is } \geq 60 \mathrm{mmHg} \text {. } \\
\text { Level of evidence: I++ } \\
\text { Grade of Recommendation: A }\end{array}$ & $\begin{array}{l}\text { Cranston et a }\left.\right|^{81} \\
\text { Nocturnal Oxygen } \\
\text { Therapy Trial }^{82} \\
\text { Medical Research } \\
\text { Council Working } \\
\text { Party } \\
\text { Croxton and Bailey } \\
\text { Güell Rous } \\
\text { Peces-Barba et al }{ }^{82} \\
\text { Task Force of }^{85} \\
\text { GesEPOC } \\
\text { GOLD } \\
\text { Qaseem et al } \\
\text { Stoller et a }{ }^{88}\end{array}$ \\
\hline & $\begin{array}{l}\text { Do not prescribe } \\
\text { corticosteroid therapy for } \\
\text { periods of }>14 \text { days or with } \\
\text { progressive reduction in } \\
\text { therapy. } \\
\text { Level of evidence: I++ } \\
\text { Grade of Recommendation: A }\end{array}$ & $\begin{array}{l}\text { Leuppi et a }{ }^{89} \\
\text { McCrory et } \mathrm{a}^{90} \\
\text { Singh et } \mathrm{al}^{91} \\
\text { Walters et } \mathrm{al}^{92} \\
\text { Albert et } \mathrm{a}^{93} \\
\text { Task Force of } \\
\text { GesEPOC } \\
\text { Miravitlles et a }{ }^{32} \\
\text { GOLD }^{13}\end{array}$ \\
\hline & $\begin{array}{l}\text { Do not perform } \\
\text { spirometry in patients with } \\
\text { known COPD. } \\
\text { Level of evidence: } 4 \\
\text { Grade of Recommendation: D }\end{array}$ & $\begin{array}{l}\text { GOLD }^{13} \\
\text { Task Force of GesEPOC } \\
\text { COPD }^{94}\end{array}$ \\
\hline $\begin{array}{l}\text { Self-care in } \\
\text { patients with } \\
\text { COPD }\end{array}$ & $\begin{array}{l}\text { Do not discontinue } \\
\text { taking inhaled medication } \\
\text { because an improvement in } \\
\text { clinical symptoms has taken } \\
\text { place. } \\
\text { Level of evidence: I++ } \\
\text { Grade of Recommendation: A }\end{array}$ & $\begin{array}{l}\text { Ingebrigtsen et } \mathrm{a}^{43} \\
\text { Restrepo et a }{ }^{95} \\
\text { Ágh et al }{ }^{96} \\
\text { Van Boven et al97 } \\
\text { Vestbo et } \mathrm{al}^{45}\end{array}$ \\
\hline & $\begin{array}{l}\text { Do not use the inhaler } \\
\text { incorrectly. }\end{array}$ & $\begin{array}{l}\text { Cecere et } \mathrm{al}^{98} \\
\text { Vestbo et } \mathrm{al}^{45}\end{array}$ \\
\hline
\end{tabular}

(Continued)
Table 2 (Continued)

\begin{tabular}{|c|c|}
\hline $\begin{array}{l}\text { Name of the practice } \\
\text { with level of evidence and } \\
\text { grade of recommendation }\end{array}$ & $\begin{array}{l}\text { Bases that justify the } \\
\text { recommendation } \\
\text { (References) }\end{array}$ \\
\hline Level of evidence: 4 & SEPAR ${ }^{99}$ \\
\hline \multirow[t]{5}{*}{ Grade of Recommendation: D } & Plaza et al $\left.\right|^{100}$ \\
\hline & Calle Rubio et al ${ }^{101}$ \\
\hline & Giner et al $^{102}$ \\
\hline & Sánchez ${ }^{103}$ \\
\hline & Plaza et a ${ }^{44}$ \\
\hline \multirow{5}{*}{$\begin{array}{l}\text { Do not stop walking due to } \\
\text { feelings of dyspnea. } \\
\text { Level of evidence: } 2++ \\
\text { Grade of Recommendation: B }\end{array}$} & Álvarez-Gutiérrez et al ${ }^{104}$ \\
\hline & García-Río 105 \\
\hline & $\mathrm{GOLD}^{13}$ \\
\hline & Miravitlles et $\mathrm{a}^{32}$ \\
\hline & Watz et al ${ }^{106}$ \\
\hline \multirow{8}{*}{$\begin{array}{l}\text { Do not take unprescribed } \\
\text { treatments. } \\
\text { Level of evidence: I++ } \\
\text { Grade of Recommendation: A }\end{array}$} & $\mathrm{GOLD}^{13}$ \\
\hline & Miravitlles et $\mathrm{a}^{32}$ \\
\hline & Tashkin et al ${ }^{107}$ \\
\hline & Vogelmeier et al ${ }^{108}$ \\
\hline & Wise et al ${ }^{109}$ \\
\hline & Decramer et al ${ }^{110}$ \\
\hline & Celli et al"'I \\
\hline & Vestbo et $\mathrm{a}^{45}$ \\
\hline
\end{tabular}

Abbreviations: COPD, chronic obstructive pulmonary disease; $\mathrm{FEV}$, forced expiratory volume in I second; GOLD, Global Initiative for Chronic Obstructive Lung Disease; $\mathrm{PaO}_{2}$, partial pressure of oxygen.

have an established diagnosis" and "Do not routinely administer intravenous steroids for patients hospitalized for acute exacerbations of asthma and COPD."

In Spain, the Ministry of Health, Social Services, and Equality launched the project titled "Commitment to Quality in Scientific Societies" ${ }^{\prime 2}$ in order to reduce unnecessary interventions. As in the present study, the initiative took unnecessary interventions to mean those for which there was no proven efficacy, practices with scant or doubtful effectiveness, or procedures that are not cost-effective. A multitude of scientific societies took part in the initiative, each represented by a panel of experts charged with producing a list of five DND recommendations. The Spanish Society of Pulmonology and Thoracic Surgery (SEPAR) established five recommendations, two of which are linked to COPD:

Do not prescribe ambulatory oxygen therapy in COPD patients where $\mathrm{PaO}_{2}$ in arterial blood is over $55 \mathrm{mmHg}$ and in the absence of exercise-related desaturation

and

Do not systematically use antibiotic therapy to treat patients with acute COPD exacerbations when there are no data on severity and when the patient only meets one Anthonisen criterion (other than sputum purulence). ${ }^{27}$ 
Table 3 Indicators used for assessment of "do not do" recommendations

\begin{tabular}{|c|c|c|}
\hline Group & “Do not do" recommendations & Indicators \\
\hline \multirow{7}{*}{$\begin{array}{l}\text { Patients } \\
\text { with stable } \\
\text { COPD }\end{array}$} & $\begin{array}{l}\text { Do not administer inhaled corticosteroids } \\
\text { as routine treatment for patients with }\end{array}$ & $\begin{array}{l}\text { Number of patients with } \mathrm{FEV},>60 \% \text { and with } 0-\mathrm{I} \text { acute } \\
\text { exacerbations in the previous year and who receive inhaled }\end{array}$ \\
\hline & $\begin{array}{l}\mathrm{FEV},>60 \% \text { and }<2 \text { acute exacerbations in } \\
\text { the previous year or in patients without an } \\
\text { overlapping COPD-asthma phenotype. }\end{array}$ & $\begin{array}{l}\text { corticosteroids as routine treatment (exclusive of patients with } \\
\text { an overlapping COPD-asthma phenotype)/number of patients } \\
\text { diagnosed with COPD who receive inhaled corticosteroids as } \\
\text { routine treatment. }\end{array}$ \\
\hline & $\begin{array}{l}\text { Do not neglect to perform spirometry as part } \\
\text { of the diagnostic work-up in patients with } \\
\text { a past history of smoking and symptoms of } \\
\text { COPD. }\end{array}$ & $\begin{array}{l}\text { Number of patients who are smokers (at least } 10 \text { pack-years) } \\
\text { over age } 35 \text { presenting respiratory symptoms and who have not } \\
\text { received spirometry/number of patients who are smokers and } \\
\text { have a diagnosis of COPD. }\end{array}$ \\
\hline & $\begin{array}{l}\text { Do not assume that patients correctly } \\
\text { administer inhaled medication in the absence } \\
\text { of proper confirmation. }\end{array}$ & $\begin{array}{l}\text { Number of patients for whom the patient chart contains } \\
\text { references to inhaled therapy (direct observation or as obtained } \\
\text { through compliance questionnaires such as Test of Adherence to } \\
\text { Inhalers [TAI])/total number of patients with COPD and inhaled } \\
\text { treatment. }\end{array}$ \\
\hline & $\begin{array}{l}\text { Do not initiate treatment without previously } \\
\text { confirming the diagnosis by spirometry. }\end{array}$ & $\begin{array}{l}\text { Number of COPD patients undergoing treatment with } \\
\text { inhalants/number of patients with spirometry-confirmed } \\
\text { COPD diagnosis. }\end{array}$ \\
\hline & $\begin{array}{l}\text { Do not change inhaled treatment without first } \\
\text { assessing treatment compliance. }\end{array}$ & $\begin{array}{l}\text { Number of patients with a justified change in inhaled treatment } \\
\text { appearing in their patient chart/number of patients in whom } \\
\text { treatment has changed over the previous year. }\end{array}$ \\
\hline & $\begin{array}{l}\text { Do not perform pulmonary function testing } \\
\text { systematically at each follow-up visit if there } \\
\text { is no change in symptoms, in the number of }\end{array}$ & $\begin{array}{l}\text { Number of spirometry studies performed in a given period } \\
\text { of time/number of follow-up consultations undertaken in the } \\
\text { same period. }\end{array}$ \\
\hline
\end{tabular}

Do not prescribe antibiotic treatment in all cases of acute exacerbation.

Do not prescribe nebulized medication in all cases of acute exacerbation.

Do not administer high-flow oxygen if oxygen saturation is $>90 \%$ or if $\mathrm{PaO}_{2}$ is $\geq 60 \mathrm{mmHg}$.

Do not prescribe home oxygen therapy following an acute exacerbation if $\mathrm{PaO}_{2}$ is $\geq 60 \mathrm{mmHg}$.

Do not prescribe corticosteroid therapy for periods of $>14$ days or with progressive reduction in therapy.

Number of COPD patients with acute exacerbations treated with antibiotic therapy/number of COPD patients with acute exacerbations.

Number of COPD patients with acute exacerbations treated with nebulized medication/number of COPD patients with acute exacerbations.

Number of patients receiving high-flow oxygen therapy who have oxygen saturation $>90 \%$ or $\mathrm{PaO}_{2} \geq 60 \mathrm{mmHg} /$ number of patients undergoing this therapy throughout a given period of time.

Number of patients prescribed home oxygen therapy following an acute exacerbation with $\mathrm{PaO}_{2} \geq 60 \mathrm{mmHg}$ /total number of cases prescribed home oxygen therapy following an acute exacerbation. Number of patients prescribed with long-term ( $>14$ days) treatment with corticosteroids/total number of patients undergoing corticosteroid therapy.

Number of patients prescribed to receive progressive reduction of corticosteroid therapy/total number of patients undergoing corticosteroid therapy.

Do not perform spirometry in patients with known COPD.

Number of spirometry studies performed during acute exacerbations in patients with previously known COPD/number of COPD patients with acute exacerbations.

Number of consultations assessing degree of compliance and proper therapy administration/total number of consultations.

patients with

Do not discontinue taking inhaled medication COPD because an improvement in clinical symptoms has taken place.

Do not use the inhaler incorrectly.

Number of consultations assessing errors in dosage or inhaler use/total number of consultations.

Do not stop walking due to feelings of dyspnea.

Daily/weekly/monthly log of distance walked compared to the results of the individual 6-minute walking test. Improved score on surveys and rating scales for physical activity or activities of daily living.

Do not take unprescribed treatments. Total number of COPD patients receiving unprescribed therapy/total number of patients with COPD. 
These working groups base their recommendations on the views of a group of subject-matter experts, selecting those practices that should not be subjected to assessment using qualitative methods. Each group works with a preliminary list of possible recommendations appearing in clinical practice guidelines, using these guidelines as a primary source. Use of this method allows for high levels of consensus on DND recommendations, although this method is limited in that, sometimes, discouraged practices are seldom used. We have taken measures to adjust for this by including recommendations that are commonly made in the context of routine practice.

In addition to the study's focus on a single disease such as COPD, one novel aspect of our article is the inclusion of DND recommendations concerning patient self-care. Specifically, we identified practices that are prevalent in COPD patient self-care despite their lack of effectiveness or even deleteriousness for these patients. Self-care in patients with COPD can improve health-related quality of life and reduce hospital admissions. ${ }^{28,29}$ Clari et al has provided evidence on the self-care behaviors and strategies that people with COPD undertake to prevent, control, and manage the physical, psychological, and social consequences of this pathology. ${ }^{30}$ Our four recommendations for self-care in patients with COPD and the proposed indicators for their evaluation could enable COPD patients to reduce the physical, psychological, and social effects of COPD, and help healthcare professionals to tailor self-care educational programs to the experiences and priorities of these patients. ${ }^{30,31}$

Another strength of this study is its use of level of evidence and grade of recommendation in accordance with $\mathrm{SIGN}^{24}$ and citations from the literature that support these recommendations.

Our study, furthermore, includes a series of proposals for follow-up of the frequency with which the cases of overuse included in the DND guidelines continue to be employed. These are COPD-related care-quality indicators that could be used by health authorities to assess outcomes. Additionally, these could be incorporated into the balanced scorecards used in care units or form part of the yearly targets set by management agreements. Proper deployment of recommendations enables appropriate oversight of the degree to which targets are being met and aids in target setting. These aspects have been scarcely used in other studies, ${ }^{26,27}$ although we believe them to be necessary to address the problem of overuse.

Due to its local setting in Spain and the implications that this setting had for the design of the study, one limitation of this research is this local nature, as results may vary in other locations. Moreover, we did not include an analysis of the frequency with which the practices selected as inadvisable are employed in current clinical practice or in patient home care. Despite this, the study focuses on clinical and self-care practices that become evident in the clinical context due to their prolonged time of use.

In addition, the study is limited by the fact that, to date, no DND indicators have been included in quality assessments and, as a result, data concerning the efficacy of these recommendations are scarce. We do, however, make a proposal which would allow for a follow-up to be conducted on the degree of uptake of these recommendations. The DND included in this study as examples of overuse were chosen because of their cost-ineffectiveness, but they are not based on empirical evidence. Moreover, the list of inappropriate practices is not supported by any investigation of real prevalence, and is based on level of agreement for opinion and experience of a small panel of experts. No quantitative study has been undertaken to measure the degree of agreement with these DND recommendations among professional groups or patient representatives, and further research should examine data on the implementation of these recommendations as well as continuous follow-up.

We can conclude from this study that DND recommendations in COPD are likely to improve management of patients with the disease by reducing the rate with which improper or scarcely cost-effective practices are used in clinical care and patient self-care. Furthermore, the use of these recommendations will lower care risks, improve physicianpatient communication, and empower patients to undertake in-home self-care.

\section{Acknowledgments}

This study was carried out under the auspices of the Madrid Society of Pulmonology and Thoracic Surgery (Neumomadrid). The work was supported by the Spanish Society of Family and Community Medicine (semFYC) and was funded without restriction by a grant from the AstraZeneca pharmaceutical company. We are grateful to Oliver Shaw (IIS-FJD) for his valuable assistance in preparing the manuscript in English.

\section{Disclosures}

F Villar-Álvarez, R Moreno-Zabaleta, JJ Mira-Solves, E CalvoCorbella, S Díaz-Lobato, F González-Torralba, A HernandoSanz, S Salgado-Aranda, B Simón-Rodríguez, and IM NavarroSoler report no conflicts of interest in this work. 
S Núñez-Palomo declares that she has written monographs or participated in courses and conferences sponsored by Boehringher, Pfizer, Astra Zéneca, GSK, and Rovi, and has no other conflicts of interest in this work.

P Vaquero-Lozano declares that in the last 5 years he has received payments for participating in meetings or congresses organized by the following pharmaceutical companies: Chiesi, AstraZeneca, Boehringer-Ingelheim, Almirall, Novartis, Sandoz, Pfizer, and Linde (Carburos Médica), and has no other conflicts of interest in this work.

\section{References}

1. University of Colorado School of Medicine. Do No Harm Project. Available from: http://www.ucdenver.edu/academics/colleges/medicalschool/departments/medicine/GIM/education/DoNoHarmProject/ Pages/Welcome.aspx. Accessed September 13, 2017.

2. Morgan DJ, Brownlee S, Leppin AL, et al. Setting a research agenda for medical overuse. BMJ. 2015;351(1):h4534.

3. Bishop TF, Cea M, Miranda Y, et al. Academic physicians' views on low-value services and the choosing wisely campaign: a qualitative study. Healthc (Amst). 2017;5(1-2):17-22.

4. Wise J. Choosing Wisely: how the UK intends to reduce harmful medical overuse. BMJ. 2017;356:j370.

5. Less is More Medicine. Available from: http://www.lessismoremedicine.com/. Accessed September 13, 2017.

6. Choosing Wisely. Clinician Lists. Philadelphia. Available from: http:// www.choosingwisely.org/clinician-lists/. Accessed September 1, 2017.

7. Chapman KR, Mannino DM, Soriano JB, et al. Epidemiology and costs of chronic obstructive pulmonary disease. Eur Respir J. 2006; 27(1):188-207.

8. Miravitlles M, Soriano JB, García-Río F, et al. Prevalence of COPD in Spain: impact of undiagnosed COPD on quality of life and daily life activities. Thorax. 2009;64(10):863-868.

9. Lozano R, Naghavi M, Foreman K, et al. Global and regional mortality from 235 causes of death for 20 age groups in 1990 and 2010: a systematic analysis for the Global Burden of Disease Study 2010. Lancet. 2012;380(9859):2095-2128.

10. Bernd L, Joan BS, Michael S, et al; BOLD Collaborative Research Group, the EPI-SCAN Team, the PLATINO Team, and the PREPOCOL Study Group. Determinants of underdiagnosis of COPD in national and international surveys. Chest. 2015;148(4):971-985.

11. European Respiratory Society. European Lung White Book. Huddersfield: European Respiratory Society Journals Ltd; 2003.

12. National Heart, Lung, and Blood Institute. Morbidity and Mortality: 2009 Chartbook on Cardiovascular, Lung and Blood Diseases. Bethesda, MD: US Department of Health and Human Services. Public Health Service, National Institutes of Health. Available from: http:// www.nhlbi.nih.gov/resources/docs/cht-book.htm; 2009. Accessed September 1, 2017.

13. Global Initiative for Chronic Obstructive Lung Disease. GOLD 2017: Global Strategy for the Diagnosis, Management and Prevention of COPD. 2017. Available from: http://goldcopd.org/gold-2017global-strategy-diagnosis-management-prevention-copd/. Accessed September 9, 2017.

14. Working group of the GesEPOC. Clinical practice guideline for the diagnosis and treatment of patients with chronic obstructive pulmonary disease (COPD) - the Spanish COPD Guideline (GesEPOC). 2017 Version. Arch Bronconeumol. 2017;53(Suppl 1):2-64.

15. Calle Rubio M, Alcázar Navarrete B, Soriano JB, et al. Clinical audit of COPD in outpatient respiratory clinics in Spain: the EPOCONSUL study. Int J Chron Obstruct Pulmon Dis. 2017;12:417-426.
16. López-Campos JL, Hartl S, Pozo-Rodriguez F, Roberts CM; European COPD Audit team. Variability of hospital resources for acute care of COPD patients: the European COPD Audit. Eur Respir J. 2014;43(3): 754-762.

17. Fan VS, Gylys-Colwell I, Locke E, et al. Overuse of short-acting betaagonist bronchodilators in COPD during periods of clinical stability. Respir Med. 2016;116:100-106.

18. Panella M, Leigheb F, Rinaldi C, Donnarumma C, Tozzi Q, Di Stanislao F. La medicina difensiva: una revisione della letteratura [Defensive Medicine: Overview of the literature]. Ig Sanita Pubbl. 2015;71(3):335-351. Italian [with English abstract].

19. Kaul S, Kirchhoff AC, Morden NE, Vogeli CS, Campbell EG. Physician response to patient request for unnecessary care. Am J Manag Care. 2015;21(11):823-832.

20. Mira JJ, Pérez-Jover V, Lorenzo S, Aranaz J, Vitaller J. La investigación cualitativa: una alternativa también válida [Qualitative research: a valid alternative.] Aten Primaria. 2004;34(4):161-169. Spanish [with English abstract].

21. Gil F, Barrasa A, Roda R. Grupos de discusión. In: Gil F, y Barassa A, Alcover CM. Técnicas grupales en contextos organizacionales [Group Techniques in Organizational Contexts]. Madrid: Pirámide; 2004: 171-188. Spanish.

22. Weiner BJ, Amick HR, Lund JL, Lee SY, Hoff TJ. Use of qualitative methods in published health services and management research: a 10-year review. Med Care Res Rev. 2011;68(1):3-33.

23. Martínez-Sahuquillo Amuedo ME, Echevarría Ruiz De Vargas MC. Métodos de consenso. Uso adecuado de la evidencia en la toma de decisiones. Método RAND/UCLA. [Consensus methods. Adequate use of evidence in decision making. RAND/UCLA method.] Rehabilitación (Madr). 2001;35(6):388-392. Spanish.

24. Scottish Intercollegiate Guidelines Network. A guideline developers' handbook. Edinburgh: SIGN. 2001. Available from: http://www.sign.ac.uk/ guidelines/fulltext/50/section6.html. Accessed September 1, 2017.

25. National Institute for Health and Care Excellence. NICE do not do prompts. Available from: https://www.nice.org.uk/sharedlearning/ nice-do-not-do-prompts. Accessed September 9, 2017.

26. Wiener RS, Ouellette DR, Diamond E, et al. An official American Thoracic Society/American College of Chest Physicians policy statement: the Choosing Wisely top five list in adult pulmonary medicine. Chest. 2014;145(6):1383-1391.

27. Ministerio de Sanidad, Servicios Sociales e Igualdad. Compromiso por la Calidad de las Sociedades Científicas en España [Commitment to the quality of the scientific societies in Spain]. Available from: http:// www.msssi.gob.es/organizacion/sns/planCalidadSNS/cal_sscc.htm. Accessed September 9, 2017. Spanish.

28. Lomundal BK, Steinsbekk A. Five-year follow-up of a one-year selfmanagement program for patients with COPD. Int J Chron Obstruct Pulmon Dis. 2012;7:87-93.

29. Gadoury MA, Schwartzman K, Rouleau M, et al; Chronic Obstructive Pulmonary Disease Axis of the Respiratory Health Network, Fonds de la recherche en santé du Québec (FRSQ). Self-management reduces both short- and long-term hospitalisation in COPD. Eur Respir J. 2005;26(5): 853-857.

30. Clari M, Matarese M, Ivziku D, De Marinis MG. Self-care of people with chronic obstructive pulmonary disease: a meta-synthesis. Patient. 2017;10(4):407-427.

31. Effing TW, Bourbeau J, Vercoulen J, et al. Self-management programmes for COPD: moving forward. Chron Respir Dis. 2012;9(1):27-35.

32. Miravitlles M, Soler-Cataluña JJ, Calle M, et al. Spanish guideline for COPD (GesEPOC). Update 2014. Arch Bronconeumol. 2014; 50(Suppl 1):1-16.

33. Vogelmeier CF, Bateman ED, Pallante J, et al. Efficacy and safety of once-daily QVA149 compared with twice daily salmeterol-fluticasone in patients with chronic obstructive pulmonary disease (ILLUMINATE): a randomised, double-blind, parallel group study. Lancet Respir Med. 2013;1(1):51-60. 
34. Zhong N, Wang C, Zhou X, et al; LANTERN Investigators. LANTERN: a randomized study of QVA149 versus salmeterol/fluticasone combination in patients with COPD. Int J Chron Obstruct Pulmon Dis. 2015: 10:1015-1026.

35. Price D, West D, Brusselle G, et al. Management of COPD in the UK primary-care setting: an analysis of real-life prescribing patterns. Int $J$ Chron Obstruct Pulmon Dis. 2014;9:889-905.

36. Vestbo J, Vogelmeier C, Small M, Higgins V. Understanding the GOLD 2011 strategy as applied to a real world COPD population. Respir Med 2014;108(5):729-736.

37. Suissa S, Patenaude V, Lapi F, Ernst P. Inhaled corticosteroids in COPD and the risk of serious pneumonia. Thorax. 2013;68(11):1029-1036.

38. Wedzicha JA, Banerji D, Chapman KR, et al; FLAME Investigators Indacaterol-Glycopyrronium versus Salmeterol-Fluticasone for COPD. N Engl J Med. 2016;374(23):2222-2234.

39. Zwar NA, Marks GB, Hermiz O, et al. Predictors of accuracy of diagnosis of chronic obstructive pulmonary disease in general practice. Med J Aust. 2011;195(4):168-171.

40. Dirven JA, Tange HJ, Muris JW, van Haaren KM, Vink G, van Schayck OC. Early detection of COPD in general practice: implementation, workload and socioeconomic status. A mixed methods observational study. Prim Care Respir J. 2013;22(3):338-343.

41. Atención Integral al paciente con Enfermedad Pulmonar Obstructiva Crónica (EPOC). Desde la Atención Primaria a la Especializada. Guía de práctica clínica. Sociedad Española de Medicina de Familia (semFYC) y Sociedad Española de Neumología y Cirugía Torácica (SEPAR) [Comprehensive care to the patient with pulmonary obstructive chronic disease (COPD. From primary care to specialization. Clinical practice guide. Spanish society of family medicine (semFYC) and Spanish society of pneumology and thoracic surgery (SEPAR)]; 2010. Available from: http://www.guiasalud.es/GPC/GPC_468_EPOC_AP_AE.pdf. Accessed September 9, 2017. Spanish.

42. Sriram KB, Percival M. Suboptimal inhaler medication adherence and incorrect technique are common among chronic obstructive pulmonary disease patients. Chron Respir Dis. 2016;13(1):13-22.

43. Ingebrigtsen TS, Marott JL, Nordestgaard BG, et al. Low use and adherence to maintenance medication in chronic obstructive pulmonary disease in the general population. J Gen Intern Med. 2015;30(1):51-59.

44. Plaza V, Fernández-Rodríguez C, Melero C, et al; TAI Study Group. Validation of the "Test of the Adherence to Inhalers" (TAI) for asthma and COPD patients. J Aerosol Med Pulm Drug Deliv. 2016;29(2): $142-152$.

45. Vestbo J, Anderson JA, Calverley PM, et al. Adherence to inhaled therapy, mortality and hospital admission in COPD. Thorax. 2009; 64(11):939-943.

46. Alexopoulos EC, Malli F, Mitsiki E, Bania EG, Varounis C, Gourgoulianis KI. Frequency and risk factors of COPD exacerbations and hospitalizations: a nationwide study in Greece (Greek obstructive lung disease epidemiology and health ecoNomics: GOLDEN study). Int J Chron Obstruct Pulmon Dis. 2015;10:2665-2674.

47. Wei L, Yang X, Li J, et al. Effect of pharmaceutical care on medication adherence and hospital admission in patients with chronic obstructive pulmonary disease (COPD): a randomized controlled study. J Thorac Dis. 2014;6(6):656-662.

48. Tommelein E, Mehuys E, Van Hees T, et al. Effectiveness of pharmaceutical care for patients with chronic obstructive pulmonary disease (PHARMACOP): a randomized controlled trial. Br J Clin Pharmacol. 2014;77(5):756-766.

49. Leiva-Fernández J, Leiva-Fernández F, García-Ruiz A, Prados-Torres D, Barnestein-Fonseca P. Efficacy of a multifactorial intervention on therapeutic adherence in patients with chronic obstructive pulmonary disease (COPD): a randomized controlled trial. BMC Pulm Med. 2014; $14: 70$.

50. Bryant J, McDonald VM, Boyes A, Sanson-Fisher R, Paul C, Melville J. Improving medication adherence in chronic obstructive pulmonary disease: a systematic review. Respir Res. 2013;14:109.
51. Fernández Villar A, López Campos JL, Represas Represas C, et al. Factors associated with inadequate diagnosis of COPD: On-Sint cohort analysis. Int J Chron Obstruct Pulmon Dis. 2015;10:961-967.

52. Buffels J, Degryse J, Liistro G. Diagnostic certainty, co-morbidity and medication in a primary care population with presumed airway obstruction: the DIDASCO2 study. Prim Care Respir J. 2009;18(1): 34-40.

53. Hardie JA, Buist AS, Vollmer WM, Ellingsen I, Bakke PS, Morkve O. Risk of over-diagnosis of COPD in asymptomatic elderly never-smokers. Eur Respir J. 2002;20(5):1117-1122.

54. Jones RC, Dickson-Spillmann M, Mather MJ, Marks D, Shackell BS Accuracy of diagnostic registers and management of chronic obstructive pulmonary disease: the Devon primary care audit. Respir Res. 2008;9:62-71

55. Miravitlles M, Andreu I, Romero Y, Sitjar S, Altés A, Anton E. Difficulties in differential diagnosis of COPD and asthma in primary care. Br J Gen Pract. 2012;62(595):68-75.

56. Miller MR, Levy ML. Chronic obstructive pulmonary disease: missed diagnosis versus misdiagnosis. BMJ. 2015;351:h3021-h3026.

57. Melani AS, Paleari D. Maintaining control of chronic obstructive airway disease: adherence to inhaled therapy and risks and benefits of switching devices. COPD. 2016;13(2):241-250.

58. Braido F, Lavorini F, Blasi F, Baiardini I, Canonica GW. Switching treatments in COPD: implications for costs and treatment adherence. Int J Chron Obstruct Pulmon Dis. 2015;10:2601-2608.

59. Kohansal R, Martinez-Camblor P, Agusti A, Buist AS, Mannino DM, Soriano JB. The natural history of chronic airflow obstruction revisited: an analysis of the Framingham off spring cohort. Am J Respir Crit Care Med. 2009;180:3-10.

60. Donaldson GC, Seemugal TAR, Bhowmik A, Wedzicha JA. Relationship between exacerbation frequency and lung function decline in chronic obstructive pulmonary disease. Thorax. 2002;57: 847-852.

61. Estrategia en EPOC del Sistema Nacional de Salud. Plan de Calidad para el Sistema Nacional de Salud. Madrid: Ministerio de Sanidad y Política Social; 2009. [COPD Strategy of the National Health System. Quality Plan for the National Health System. Madrid: Ministry of Health and Social Policy; 2009]. Spanish.

62. Peces-Barba G, Barberà JA, Agustí A, et al. Diagnosis and management of chronic obstructive pulmonary disease: joint guidelines of the Spanish Society of Pulmonology and Thoracic Surgery (SEPAR) and the Latin American Thoracic Society (ALAT). Arch Bronconeumol. 2008;44(5): 271-281.

63. Sapey E, Stockley RA. COPD exacerbations. 2: aetiology. Thorax. 2006;61(3):250-258.

64. Vollenweider DJ, Jarrett H, Steurer-Stey CA, Garcia-Aymerich J, Puhan MA. Antibiotics for exacerbations of chronic obstructive pulmonary disease. Cochrane Database Syst Rev. 2012;12:CD010257.

65. Soler N, Agustí C, Angrill J, Puig de la Bellacasa J, Torres A. Bronchoscopic validation of the significance of sputum purulence in severe exacerbations of chronic obstructive pulmonary disease. Thorax. 2007; 62:29-35.

66. Miravitlles M, Monsó E, Mensa J, et al. [Antimicrobial treatment of exacerbation in chronic obstructive pulmonary disease: 2007 consensus statement.] Arch Bronconeumol. 2008;44(2):100-108. Spanish [with English abstract].

67. Boixeda R, Almagro P, Díez-Manglano J, et al. Bacterial flora in the sputum and comorbidity in patients with acute exacerbations of COPD Int J Chron Obstruct Pulmon Dis. 2015;10:2581-2591.

68. Turner MO, Patel A, Ginsburg S, FitzGerald JM. Bronchodilator delivery in acute airflow obstruction. A meta-analysis. Arch Intern Med. 1997;157(15):1736-1744.

69. Brocklebank D, Ram F, Wright J, et al. Comparison of the effectiveness of inhaler devices in asthma and chronic obstructive airways disease: a systematic review of the literature. Health Technol Assess. 2001; 5(26):1-149. 
70. Dolovich MB, Ahrens RC, Hess DR, et al; American College of Chest Physicians; American College of Asthma, Allergy, and Immunology. Device selection and outcomes of aerosol therapy: evidence-based guidelines: American College of Chest Physicians/American College of Asthma, Allergy, and Immunology. Chest. 2005;127(1): 335-371.

71. Tashkin DP, Klein GL, Colman SS, Zayed H, Schonfeld WH. Comparing COPD treatment: nebulizer, metered dose inhaler, and concomitant therapy. Am J Med. 2007;120:435-441.

72. Royal United Hospital Bath. NHS. Oxygen therapy administration Policy and Guidelines: the administration of short burst, sustained (medium term) and emergency oxygen to adults in hospital. London; 2008.

73. Driscoll R, Howard L, Davison A. British Thoracic Society: Guideline for emergency oxygen use in the adult patients. Thorax. 2008;63(s6): vi1-vi68.

74. Rachmale S, Li G, Wilson G, Malinchoc M, Gajic O. Practice of excessive FIO2 and effect on pulmonary outcomes in mechanically ventilated patients with acute lung injury. Respir Care. 2012;57: 1887-1893.

75. Miravitlles M, Soler-Cataluña J, Calle M, et al; Spanish Society of Pulmonology and Thoracic Surgery. Spanish COPD Guidelines (GesEPOC): pharmacological treatment of stable COPD. Spanish Society of Pulmonology and Thoracic Surgery. Arch Bronconeumol. 2012;48(7):247-257.

76. American Thoracic Society. Standards for the diagnosis and care of patients with chronic obstructive pulmonary disease. Am J Respir Crit Care Med. 1995;152(5 Pt 2):S77-S121.

77. BTS guidelines for the management of chronic obstructive pulmonary disease. Thorax. 1997;52(Suppl 5):1-28.

78. Barberá J, Peces-Barba G, Agustí A, et al. Clinical guidelines for the diagnosis and treatment of chronic obstructive pulmonary disease. Arch Bronconeumol. 2001;37:297-316.

79. Siafakas NM, Vermeire P, Pride NB, et al. Optimal assessment and management of chronic obstructive pulmonary disease (COPD). European Respiratory Society consensus statement. Eur Respir J. 1995;8(8): 1398-1420.

80. Pauwels RA, Buist AS, Calverley PM, Jenkins CR, Hurd SS; GOLD Scientific Committee. Global strategy for the diagnosis, management, and prevention of chronic obstructive pulmonary disease. NHLBI/WHO Global Initiative for Chronic Obstructive Lung Disease (GOLD) Workshop summary. Am J Respir Crit Care Med. 2001;163(5):1256-1276.

81. Cranston JM, Crockett AJ, Moss JR, Alpers JH. Domiciliary oxygen for chronic obstructive pulmonary disease. Cochrane Database Syst Rev. 2005;4:CD001744.

82. Nocturnal Oxygen Therapy Trial group. Continuous or nocturnal oxygen therapy in hypoxemic chronic obstructive lung disease. Ann Intern Med. 1980;93:391-398.

83. Report of the Medical Research Council Working Party. Long-term domiciliary oxygen therapy in chronic hypoxic cor pulmonale complicating chronic bronchitis and emphysema. Lancet. 1981;1(8222): 681-685.

84. Croxton TL, Bailey WC. Long-term oxygen treatment in chronic obstructive pulmonary disease: recommendations for future research: an NHLBI workshop report. Am J Respir Crit Care Med. 2006;174(4): 373-378.

85. Güell Rous R. Long-term oxygen therapy: are we prescribing appropriately? Int J Chron Obstruct Pulmon Dis. 2008;3(2):231-237.

86. Task Force of GesEPOC. Clinical Practice Guideline for the Diagnosis and Treatment of Patients with Chronic Obstructive Pulmonary Disease (COPD) - Spanish Guideline for COPD (GesEPOC). Arch Bronconeumol. 2012;48:2-58.

87. Qaseem A, Wilt TJ, Weinberger SE, et al; American College of Physicians; American College of Chest Physicians; American Thoracic Society; European Respiratory Society. Diagnosis and management of stable chronic obstructive pulmonary disease: a clinical practice guideline update from the American College of Physicians, American College of Chest Physicians, American Thoracic Society, and European Respiratory Society. Ann Intern Med. 2011;155(3):179-191.
88. Stoller JK, Panos RJ, Krachman S, Doherty DE, Make B; Long-Term Oxygen Treatment Trial Research Group. Oxygen therapy for patients with COPD: current evidence and the long-term oxygen treatment trial. Chest. 2010;138(1):179-187.

89. Leuppi JD, Schuetz P, Bingisser R, et al. Short-term vs conventional glucocorticoid therapy in acute exacerbations of chronic obstructive pulmonary disease: the REDUCE randomized clinical trial. JAMA. 2013;309(21):2223-2231.

90. McCrory DC, Brown C, Gelfand SE, Bach PB. Management of acute exacerbations of COPD: a summary and appraisal of published evidence. Chest. 2001;119(4):1190-1209.

91. Singh JM, Palda VA, Stanbrook MB, Chapman KR. Corticosteroid therapy for patients with acute exacerbations of chronic obstructive pulmonary disease: a systematic review. Arch Intern Med. 2002;162: 2527-2536.

92. Walters JA, Gibson PG, Wood-Baker R, Hannay M, Walters EH. Systemic corticosteroids for acute exacerbations of chronic obstructive pulmonary disease. Cochrane Database Syst Rev. 2009;1: CD001288.

93. Albert RK, Martin TR, Lewis SW. Controlled clinical trial of methylprednisolone in patients with chronic bronchitis and acute respiratory insufficiency. Ann Intern Med. 1980;92:753-758.

94. Chronic Obstructive Pulmonary Disease in Pulmonary Disease in Over 16s: Diagnosis and Management. Available from: https://www.nice. org.uk/guidance/cg101. Accessed January 9, 2017.

95. Restrepo RD, Alvarez MT, Wittnebel LD, et al. Medication adherence issues in patients treated for COPD. Int J Chron Obstruct Pulmon Dis. 2008;3(3):371-384.

96. Ágh T, Dömötör P, Bártfai Z, Inotai A, Fujsz E, Mészáros Á. Relationship between medication adherence and health-related quality of life in subjects with COPD: a systematic review. Respir Care. 2015;60: 297-303.

97. Van Boven JF, Chavannes NH, van der Molen T, Rutten-van Mölken MP, Postma MJ, Vegter S. Clinical and economic impact of non-adherence in COPD: a systematic review. Respir Med. 2014;108:103-113.

98. Cecere LM, Slatore CG, Uman JE, et al. Adherence to long-acting inhaled therapies among patients with chronic obstructive pulmonary disease (COPD). COPD. 2012;9(3):251-258.

99. López Viña A, Clarà PC, Moral VP, et al. [SEPAR-ALAT consensus for inhaled therapies]. Arh Bronconeumol. 2013;49(Suppl 1):2-14. Spanish [with English abstract].

100. Plaza V, Calle M, Molina J, et al. Validación externa de las recomendaciones del consenso multidisciplinar sobre terapia inhalada [External validation of the recommendations of the multidisciplinary consensus about inhaled therapies.] Arch Bronconeumol. 2012;48(6):189-196. Spanish [with English abstract].

101. Calle Rubio M, Molina París J, Plaza Moral V, Quirce Gancedo S, Sanchís Aldás J, Viejo Bañuelos JL, editors. Terapia inhalada. Teoría y práctica [Inhaled therapy. Theory and practice]. Madrid: Editorial Luzán 5; 2010:132-138. Spanish.

102. Giner J, Basualdo LV, Casan P, et al. Guideline for the use of inhaled drugs. The Working Group of SEPAR: the Nursing Area of the Sociedad Española de Neumología y Cirugía Torácica. Arch Bronconeumol. 2000;36(1):34-43.

103. Sánchez E. Inhalando sonrisas, Algo más sobre inhaladores [Inhaling smiles, something more on inhalers]. Sociedad Española de Neumología y Cirugía Torácica (SEPAR). Editorial Respira. Barcelona; 2012. Spanish.

104. Álvarez-Gutiérrez FJ, Miravitlles M, Calle M, Gobartt E, López F, Martín A; Grupo de Estudio EIME. Impact of chronic obstructive pulmonary disease on activities of daily living: results of the EIME multicenter study. Arch Bronconeumol. 2007;43(2):64-72.

105. García-Río F. Daily living activity in COPD: a new parameter to be evaluated? Med Clin. 2007;129:337-338.

106. Watz H, Pitta F, Rochester CL, et al. An official European Respiratory Society statement on physical activity in COPD. Eur Respir J. 2014; 44(6):1521-1537. 
107. Tashkin DP, Celli B, Senn S, et al; UPLIFT Study Investigators. A 4-year trial of tiotropium in chronic obstructive pulmonary disease. N Engl J Med. 2008;359(15):1543-1554.

108. Vogelmeier C, Hederer B, Glabb T, et al; POET-COPD Investigators. Tiotropium vs salmeterol for the prevention of exacerbations of COPD. N Engl J Med. 2011;364(12):1093-1110.

109. Wise RA, Anzueto A, Cotton D, et al; TIOSPIR Investigators. Tiotropium respimat inhaler and the risk of death in COPD. $N$ Engl $J$ Med. 2013;369(16):1491-1501.
110. Decramer M, Celli B, Kesten S, Lystig T, Mehra S, Tashkin DP UPLIFT Investigators. Effect of tiotropium on outcomes in patients with moderate chronic obstructive pulmonary disease (UPLIFT): a prespecified subgroup analysis of a randomised controlled trial. Lancet. 2009;374(9696):1171-1178.

111. Celli B, Decramer M, Kesten S, Liu D, Mehra S, Tashkin DP; UPLIFT Study Investigators. Mortality in the 4-year trial of tiotropium (UPLIFT) in patients with chronic obstructive pulmonary disease. Am J Respir Crit Care Med. 2009;180(10):948-955.

International Journal of COPD

\section{Publish your work in this journal}

The International Journal of COPD is an international, peer-reviewed journal of therapeutics and pharmacology focusing on concise rapid reporting of clinical studies and reviews in COPD. Special focus is given to the pathophysiological processes underlying the disease, intervention programs, patient focused education, and self management protocols.

\section{Dovepress}

This journal is indexed on PubMed Central, MedLine and CAS. The manuscript management system is completely online and includes a very quick and fair peer-review system, which is all easy to use. Visit http://www.dovepress.com/testimonials.php to read real quotes from published authors.

Submit your manuscript here: http://www.dovepress.com/international-journal-of-chronic-obstructive-pulmonary-disease-journal 